\title{
Professor S. HOWARD HANSFORD
}

Professor S. Howard Hansford, Emeritus Professor of the University of London, died on 1 April, 1973. After study at London University, he joined the R.F.A. in 1918 as a Second Lieutenant. Between his discharge from war service and his succession to the chair in the University, Hansford was partner in a firm of China and Japan merchants, member of an intelligence team at the Foreign Office during the late war, then a Chinese Government Scholar at London University. From 1955 to 1966 he occupied the chair of Chinese Art and Archaeology and thereafter lived in retirement until his death.

An important part of Hansford's academic work may be seen as a prolongation of his predecessor Yetts's literary and limited study of the Chinese bronze age, based, as it then had to be, on the interpretation of bronze vessels deriving from the antique trade and divorced from documentation of discovery and accompaniment. Hansford's more original contribution to Chinese studies lay in the aleatory field of jade. Technique, lore, and dating of this craft, in that order of emphasis and conclusiveness, claimed his attention during his pre-university years as well as the time of his headship of the Percival David Foundation of Chinese Art (the post held concurrently with his chair).

The chief monuments to Hansford's interests are his monograph on jade carving, published in 1950, and the book which he developed from it to appear as Chinese carved jades in 1968. In 1957 his catalogue of the bronzes, jades, and sculptures in the Seligman Collection had made this important material available for general study. His Glossary of Chinese art and archaeology (1954) is a work typifying its author's thoroughness in nomenclature study of the kind Yetts had taken over from Chinese antiquarianism, with laudable pedagogical intent.

It would be idle to deny the awkwardness Hansford felt in attempting to continue his side of the study of Chinese antiquity in the difficult circumstances created by the establishment of the People's Republic. He was not much minded to make allowance for the part that ideological prejudice and nationalistic brashness, as he saw them, played in the new archaeology and its publication. He left his job at the moment when the Great Cultural Revolution had put a stop to any cultural activity in China perceptible from the outside. His mood was not untouched by pessimism, but still his encouragement to younger men to persevere in their endeavours never abated.

Hansford's lasting achievement was to launch jade study on a new level of seriousnessnew for the East (would it attend) no less than the West. His persistence, conservatism, and exemplary caution in scholarship are qualities which deserve more express acclaim now than they did a generation ago. The fruits of these qualities, as we may see in Hansford's works, are enduring and useful, not marked out by fashionable scholastic brilliance and transient theory. Hansford was always modest, and to pupils and friends invariably attentive and painstakingly helpful.

WiLliam Watson. 